\title{
Selectivity of multifilament trammel and gillnets for common carp (Cyprinus carpio L., 1758) in Lake Marmara
}

\section{Marmara Gölü’nde sazan balığı (Cyprinus carpio L., 1758) için multifilament fanyalı ve galsama uzatma ağlarının seçiciliği}

\author{
Celalettin Aydın ${ }^{\text {* }}$ - Mehmet Cilbiz² - Ali İlhan1 - Hasan Musa Sarı1 \\ 1 Ege University, Faculty of Fisheries, 35100 Bornova-Izmir, Turkey \\ 2 Fisheries Research Institute, Eğirdir- Isparta, Turkey \\ *Corresponding author: caydina@gmail.com
}

Received date: 29.02.2016 Accepted date: 17.05.2016

How to cite this paper:

Aydın, C., Cilbiz, M., Illhan, A. \& Sarı, H.M. (2016). Selectivity of multifilament trammel and gillnets for common carp (Cyprinus carpio L., 1758) in Lake Marmara. Ege Journal of Fisheries and Aquatic Sciences, 33(3): 183-192. doi: 10.12714/egejfas.2016.33.3.01

\begin{abstract}
This study was aimed to estimate the selectivity properties of multifilament trammel and gillnets for common carp (Cyprinus carpio L., 1758) in Marmara Lake in Manisa, Turkey. Trammel and gillnets of 4, 6, 8, and $10 \mathrm{~cm}$ stretched mesh size and $210 \mathrm{~d} / 2 \mathrm{no}$ twine thickness were tested in the Marmara Lake. In addition, selectivity parameter of 11, 12,13 and $14 \mathrm{~cm}$ mesh size of trammel and gillnets were modelled. SELECT method was used to estimate the selectivity parameters. Experiments were carried out monthly in the three different stations identified eastern, middle and western areas which represent longitudinal length of the lake. A total of 36 trials were conducted both nets. A total of 119 common carps were caught ranges between $11.3-49.0 \mathrm{~cm}$ total lengths. According to the $\mathrm{Bi}$ - normal model, which gave the lowest deviance for both trammel and gillnets, selectivity curves were estimated for 4, 6, 8, 10,11,12,13 and $14 \mathrm{~cm}$ stretched mesh size modelled lengths as $12.98,19.47,25.96,32.45,35.70,38.94,42.19$ and $45.43 \mathrm{~cm}$ for trammel nets, $12.40,18.60,24.80,31.00,34.10,37.20,40.30$ and $43.40 \mathrm{~cm}$ for gillnets, respectively. When considering minimum landing size $(40 \mathrm{~cm}$ total length), it is recommended that both nets under $13 \mathrm{~cm}$ mesh size should be prohibited for common carp fishery in the Lake Marmara.
\end{abstract}

Keywords: Trammel net, gillnets, common carp Cyprinus carpio, size selectivity, Lake Marmara

Öz: : Bu çalışmada, Marmara Gölü’ndeki sazan balığı (Cyprinus carpio L., 1758) için multifilament fanyalı ve galsama uzatma ağlarının seçicilik özelliklerinin tahmin edilmesi amaçlanmıștır. 210d/2 ip kalınlığına ve 4,6,8,10 cm ağ gözü açıkığına sahip fanyalı ve galsama ağlar Marmara Gölü'nde test edilmiştir. Ayrıca elde edilen verilerle $11,12,13$ ve $14 \mathrm{~cm}$ göz açıkığındaki fanyalı ve galsama uzatma ağlarının optimum yakalama boyları için modelleme yapılmıştır. Seçicilik parametrelerinin tahmininde SELECT metot kullanıımıştır. Avcılık denemeleri gölü yatay olarak temsil edecek şekilde; batı, orta ve doğu kısmından belirlenen üç farkı istasyonda aylık olarak yürütülmüştür. Hem fanyalı hem de galsama ağları ile 36 adet avcılık denemesi yapılmıştır. $11,3-49,0 \mathrm{~cm}$ boy aralığında toplam 119 adet sazan yakalanmıştır. Hem fanyalı hem de galsama ağları için en düşük sapmayı veren Bi-normal modele göre; 4, 6, 8, 10, 11, 12, 13 ve 14 cm göz açıklığındaki fanyalı ağların model boyları; 12,98, 19,47, 25,96, 32,45, 35,70,38,94 ve 42,19 cm, aynı göz açıklığındaki galsama ağları için model boyları 12,40, 18,60, 24,80, $31,00,34,10,37,20,40,30$ ve 43,40 cm, olarak tahmin edilmiştir. Sazan balığının $40 \mathrm{~cm}$ minimum avlama boyu göz önüne alındığında, $13 \mathrm{~cm}$ göz açıklığının altındaki hem galsama hem de fanyalı uzatma ağlarının yasaklanması tavsiye edilmektedir.

Anahtar kelimeler: Fanyalı uzatma ağı, galsama uzatma ağı, sazan balığı, Cyprinus carpio, boy seçiciliği, Marmara Gölü

\section{INTRODUCTION}

Common carp (Cyprinus carpio L., 1758) is one of the main target species in Turkey Inland fisheries. This species distributes through Turkey (Cilbiz et al., 2015) and landings reached $13718 \mathrm{t}$ in 2005 and then decreased to $8036 \mathrm{t}$ in 2014 (TUIK, 2015). This might be due to; overfishing, pollution, diseases and parasites habitat degradation and invasive species (such as Carassius gibelio reported by Emiroğlu (2011)).
Due to the prohibited to using monofilament nets in Turkey since 1 September 2010 (Anonymous, 2008), fishers have been handled multifilament net. However, selectivity properties of multifilament nets is unknown for carp fishery. There is a minimum mesh size regulation in Turkey inland fisheries. Notwithstanding, different provincial directorate announcement employed different minimum mesh size utilization. Such as, Provincial Directorate of Food, Agriculture and Live Stock in Konya is announcement $13 \mathrm{~cm}$, while Isparta is declarate 11 $\mathrm{cm}$. 
Lake Marmara is located within the boundaries of Manisa province in the Aegean region of Turkey. Although an alluvial bank lake, it is gain of the dam lake function by means of artisanal raceway and bank (Arı and Derinöz, 2011). İlhan and Sarı (2013) reported that there are 15 fish species (Atherina boyeri, Alburnus battalgilae, Cyprinus carpio, Carassius gibelio, Chondrostoma holmwoodii, Capoeta bergamae, Ladigesocypris mermere, Pseudorasbora parva, Petroleuciscus symrnaeus, Rhodeus amarus, Vimba vimba, Cobitis fahirae, Sander lucioperca, Gambusia affinis and Knipowitschia mermere) in the Lake Marmara. It is also reported that one of the most commercial fish species in the lake is the $C$. carpio and then Sander lucioperca, Siluris glanis and Alburnus battalgilae (Illhan and Sarı, 2013).

There is some selectivity studies conducted on the species. Balık (1999), Özyurt and Avşar (2005) and Yalçın (2006) estimated monofilament gillnet selectivity by Holt (1963); Carol and García-Berthou (2007) determined monofilament gillnet selectivity by SELECT method. Cilbiz et al. (2015) analysed monofilament trammel net selectivity by SELECT method in Turkey. However, there is no study conducted on estimating selectivity properties of both multifilament trammel and gillnet in same time and area for freshwater fish.
This study was aimed to estimate the selectivity properties of multifilament trammel and gillnets with $4,6,8$, and $10 \mathrm{~cm}$ mesh size for common carp in Marmara Lake in Manisa. In addition, selectivity parameter of $11,12,13$ and $14 \mathrm{~cm}$ mesh size of trammel and gillnets were modelled. It is the first time presented both multifilament trammel and gillnets selectivty proporties in same fishing area and experiment period.

\section{MATERIALS AND METHODS}

\section{Study area}

The study was conducted on Lake Marmara which altitude is $79 \mathrm{~m}$ and surface between $3200-6800$ ha based on depth differences. Average depths are about 3-4 $\mathrm{m}$ but lake depth is changes coupled with year by year (Arı and Derinöz, 2011). Experiments were carried out in three different stations identified eastern, middle and western areas which represent the longitudinal length of the lake. In order to ensure homogeneity between stations, twelve nets were used on each station (totally 36 nets) on a monthly basis in 2012 (Figure 1).

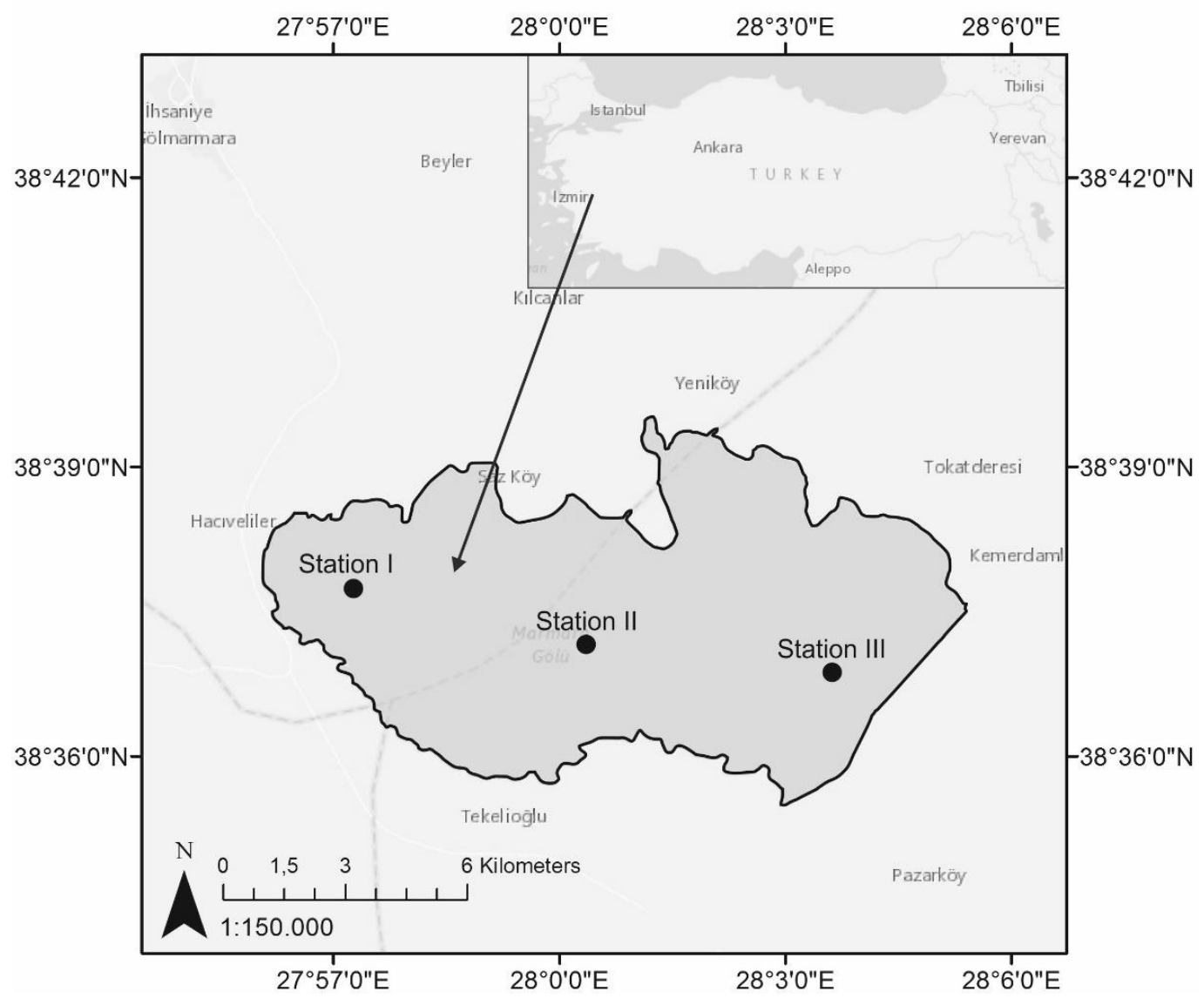

Figure 1. Lake Marmara and sampling stations 


\section{Sampling and data collection}

Multifilament 4, 6, 8 and $10 \mathrm{~cm}$ stretched mesh size of both trammel and gillnets were used in the experiments. Each gillnet has $35 \mathrm{~m}$ in length and 210 denier/2 twine thickness. All nets vertical mesh numbers were 50 meshes in depths and each hanging ratio $(E)$ was 0.50 . Trammel nets inner panels have same character with gillnets. Experimental nets information is given in Figure 2. All nets were connected each other with float line and lead line randomly and set at the bottom of sampling station in the afternoon and was hauled the following day. Average fishing time for per catching operation was 16 hours. Fish were classified depending on the nets. Total lengths were measure as $1 \mathrm{~mm}$ precision with measurement board.

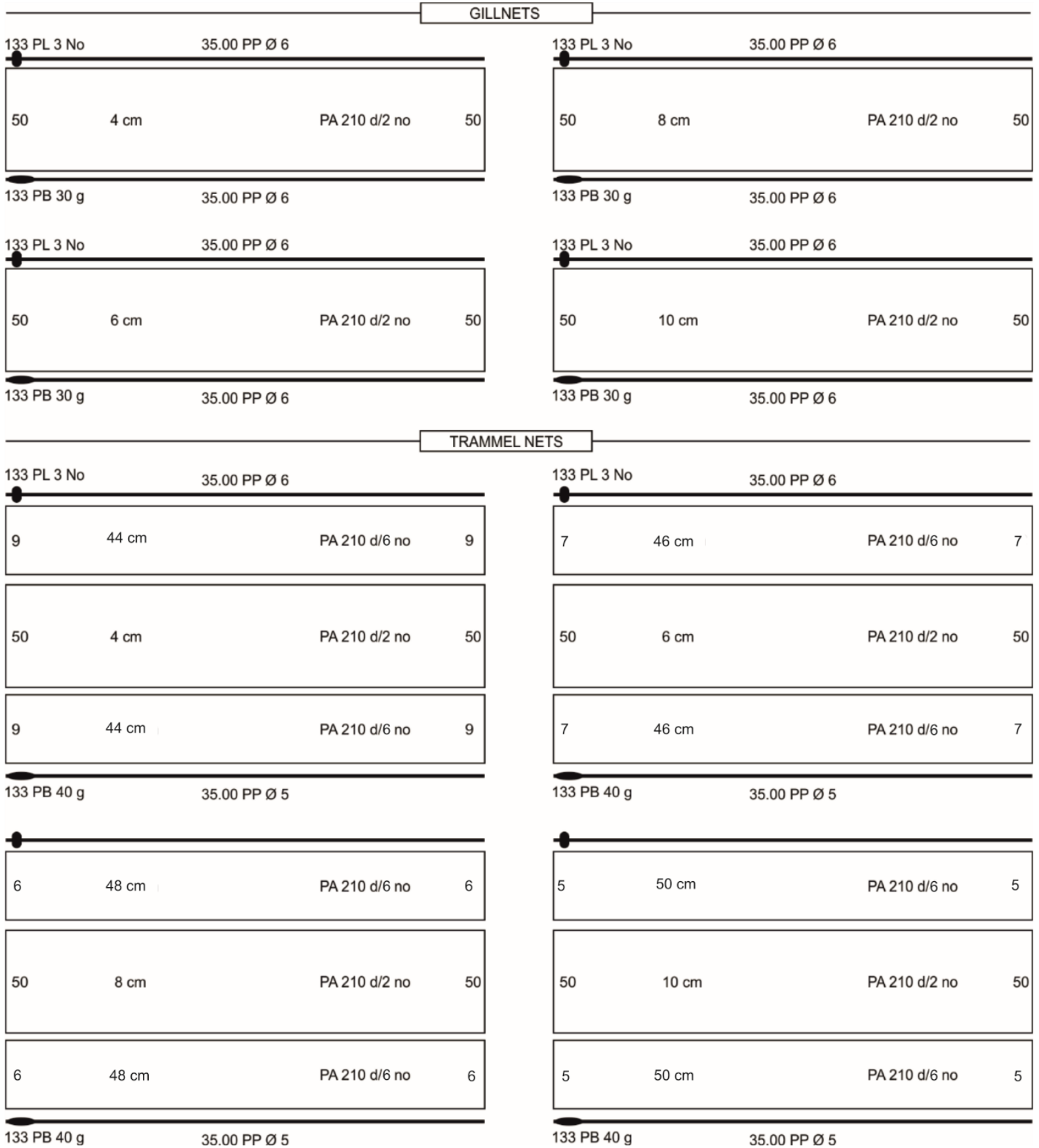

Figure 2. Technical plan of trial nets (not in scale) 


\section{Selectivity analysis}

As indirect estimation method, SELECT (Share Each Length's Class Catch Total) method was used to determine selectivity (Millar, 1992; Millar and Holst, 1997; Millar and Fryer, 1999). Data were analysed by R-codes which developed by Millar (2009) and Millar (2010) in R version 3.1.2. Length selectivity of each mesh size was described by five different models (normal location, normal scale, gamma, lognormal and bi-normal) of the SELECT method (Millar and Fryer, 1999; Park et al., 2011). The equations for each model are given in below.

Normal Location :

$$
\exp \left(-\frac{\left(L-k \cdot m_{j}\right)^{2}}{2 \sigma^{2}}\right)
$$

Normal Scale :

$$
\exp \left(-\frac{\left(L-k_{1} \cdot m_{j}\right)^{2}}{2 k_{2}^{2} \cdot m_{j}^{2}}\right)
$$

Log-Normal :

$$
\frac{1}{L} \exp \left(\mu+\log \left(\frac{m_{j}}{m_{1}}\right)-\frac{\sigma^{2}}{2}-\frac{\left(\log (L)-\mu-\log \left(\frac{m_{j}}{m_{1}}\right)\right)^{2}}{2 \sigma^{2}}\right)
$$

Gamma :

$$
\left(\frac{L}{(\alpha-1) \cdot k \cdot m_{j}}\right)^{\alpha-1} \exp \left(\alpha-1-\frac{L}{k \cdot m_{j}}\right)
$$

Bi-modal :

$$
\exp \left(-\frac{\left(L-k_{1} \cdot m_{j}\right)^{2}}{2 k_{2}^{2} \cdot m_{j}^{2}}\right)+c \cdot \exp \left(-\frac{\left(L-k_{3} \cdot m_{j}\right)^{2}}{2 k_{4}^{2} \cdot m_{j}^{2}}\right)
$$

Park et al. (2011) reported that determinated selectivity curve for the smallest mesh scale proportionally to mesh size for all other mesh sizes in their study that was carried out with Millar's (2010) R-codes. Due to the trial nets estimated value gave below the minimum landing size $(40 \mathrm{~cm})$, we also modelled for 11, 12, 13 and $14 \mathrm{~cm}$ mesh size using same constant.

The most suitable model was chosen taking into account the lowest deviation value. The Kolmogorov-Smirnov (K-S) test was used to compare the catch size frequency distributions of the common carp caught for gillnet and trammel nets separately (Siegel and Castellan, 1989; Karakulak and Erk, 2008). The ttest was utilized total length difference between same mesh size.

\section{RESULTS}

A total of 119 common carp were caught. Those which 79 of them trammel and 40 of them with gillnet. Trammel nets caught more $97 \%$ individuals than gillnet. The most effective net was found as $8 \mathrm{~cm}$ mesh size for both trammel net (58.2\%) and gillnet (65.0\%) (Table 1). Minimum lengths class were very close for both trammel nets and gillnet, while there are gap between maximum lengths class (Table 1, Figure 3 ). In addition, carp length ranges very narrow gillnet then trammel nets for same mesh size.

Depends on increasing mesh size, average total lengths of the specimens in gillnet was linearly increase, however, slight fluctuations were observed in trammel nets. On the basis of same mesh size, trammel nets specimens average length generally higher then gillnet (Figure 3).

Table 1. Common carp catch composition obtained from experiments (N: number of fish, TL: total lengths, Se: Standard error, Min: Minimum, Max: Maximum)

\section{Trammel Nets}

\begin{tabular}{ccccc}
$\begin{array}{c}\text { Mesh size } \\
(\mathrm{cm})\end{array}$ & $\mathrm{N}$ & $\mathrm{N}(\%)$ & $\mathrm{TL} \pm \mathrm{Se}(\mathrm{cm})$ & $\begin{array}{c}\text { Min. }- \text { Max. } \\
(\mathrm{cm})\end{array}$ \\
\hline 4 & 11 & 13.9 & $20.30 \pm 2.84$ & $11.3-34.3$ \\
6 & 17 & 21.5 & $29.08 \pm 2.08$ & $17.8-43.5$ \\
8 & 46 & 58.2 & $27.17 \pm 0.58$ & $21.5-37.70$ \\
10 & 5 & 6.3 & $30.80 \pm 4.85$ & $21.5-49.0$
\end{tabular}

\section{Gillnets}

\begin{tabular}{cccc}
\hline $\mathrm{N}$ & $\mathrm{N}(\%)$ & $\mathrm{TL} \pm \mathrm{Se}(\mathrm{cm})$ & $\begin{array}{c}\text { Min. }- \text { Max. } \\
(\mathrm{cm})\end{array}$ \\
\hline 4 & 10 & $11.60 \pm 0.12$ & $11.3-11.8$ \\
5 & 12.5 & $18.08 \pm 0.59$ & $16.8-20.3$ \\
26 & 65 & $25.42 \pm 0.45$ & $21.1-30.7$ \\
5 & 12.5 & $28.88 \pm 1.06$ & $25.4-31.9$
\end{tabular}




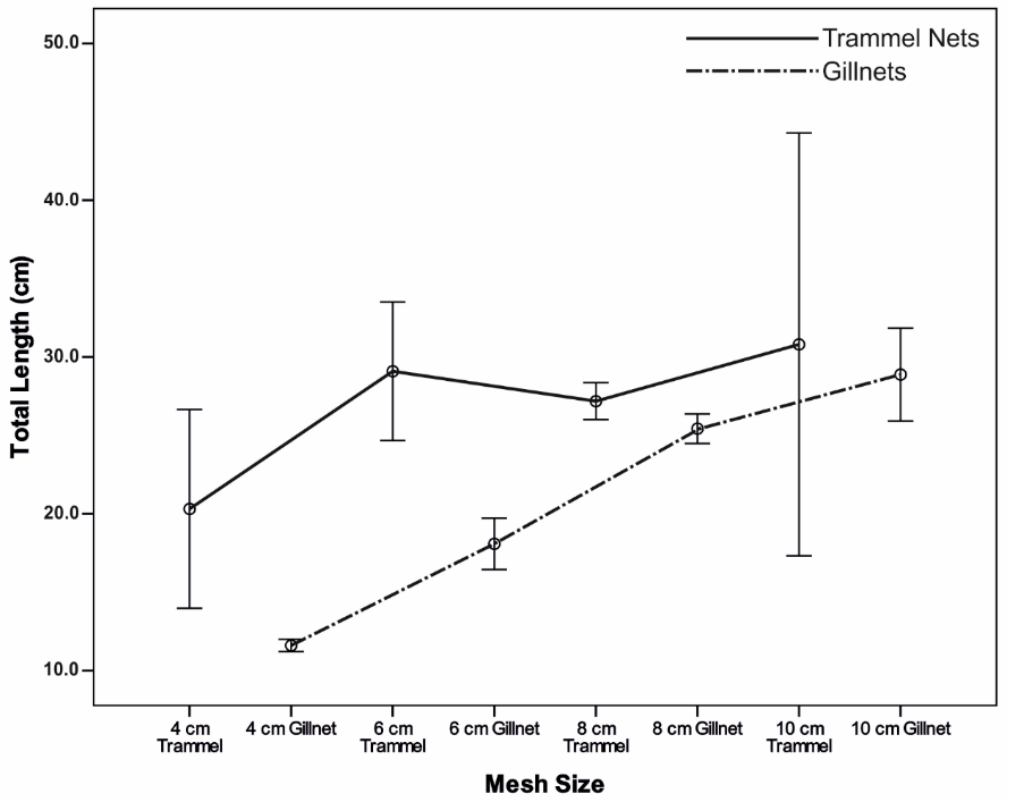

Figure 3. Error bar plot of total length by different mesh size

When comparing model deviance, bi-normal model was best suitable model (lowest deviance) for trammel nets (Table 2). Selectivity curves drafted by that model (Figure 4), k1 determined as 2.57 for $1 \mathrm{~cm}$ precision mesh size. Deviance of other model were founded 103.80, 111.81, 97.95 and 102.71 for normal location, normal scale, gamma and lognormal, respectively. Similarly to trammel nets, best suitable model determined as bi-normal for gillnets by lowest deviance (7.60) and selectivity curves drafted by bi-normal model (Table 3 , Figure 5). $\mathrm{k} 1$ determined as 2.52 for trammel nets.

Deviance of other model were founded $13.78,10.86,10.35$ and 10.18 for normal location, normal scale, gamma and lognormal, respectively.
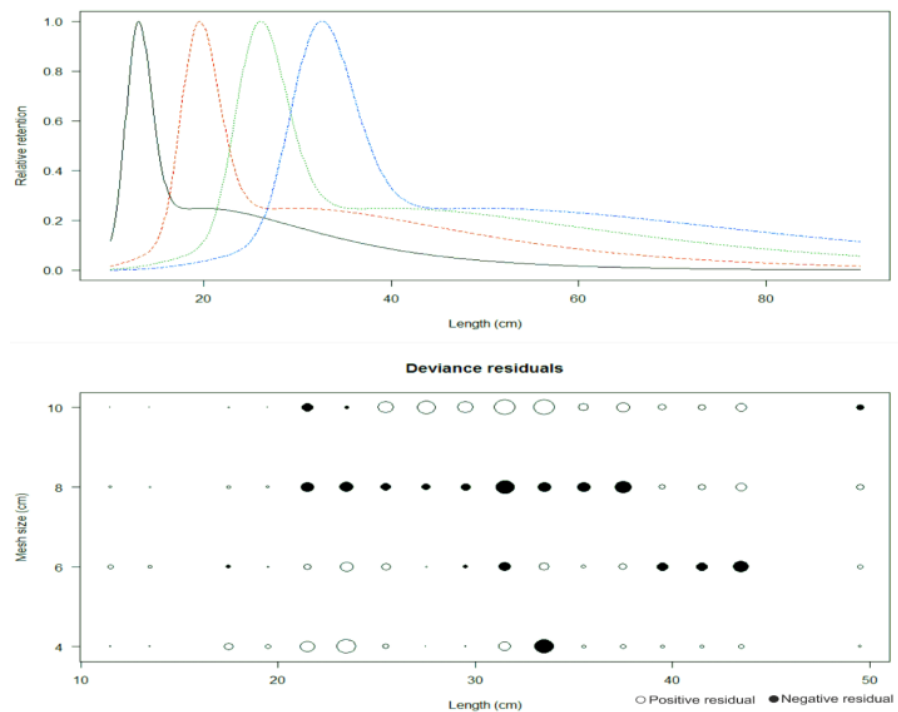

Figure 4. Selectivity curves and deviance residual plots of trammel nets for the $C$. carpio 
Table 2. Selectivity model parameters of common carp and estimated selection curves for the $4 \mathrm{~cm}$ mesh size for the trammel nets

\begin{tabular}{|c|c|c|c|c|c|c|c|c|}
\hline \multirow[b]{2}{*}{ Model } & \multirow[b]{2}{*}{ Parameters } & \multicolumn{7}{|c|}{ Equal fishing power } \\
\hline & & Estimates & Mode 1 & Spread 1 & Mode 2 & Spread 2 & Deviance & df \\
\hline \multirow{2}{*}{$\begin{array}{l}\text { Normal } \\
\text { location }\end{array}$} & $k$ & $3.82(0.21)$ & $15.29(0.8)$ & $9.87(1.37)$ & - & - & 103.80 & 49 \\
\hline & $\sigma$ & $9.87(1.37)$ & & & & & & \\
\hline \multirow[t]{2}{*}{ Normal scale } & $k_{1}$ & $4.07(0.48)$ & $16.30(1.92)$ & $3.46(1.83)$ & - & - & 111.81 & 49 \\
\hline & $k_{2}$ & $4.48(1.94)$ & & & & & & \\
\hline \multirow[t]{2}{*}{ Lognormal } & $\mu_{1}$ & $2.84(0.06)$ & $15.04(0.89)$ & $7.09(1.33)$ & - & - & 97.95 & 49 \\
\hline & $\sigma$ & $0.37(0.04)$ & & & & & & \\
\hline \multirow[t]{2}{*}{ Gamma } & $k$ & $0.62(0.17)$ & $15.66(1.03)$ & $6.75(1.04)$ & - & - & 102.71 & 49 \\
\hline & $a$ & $7.24(1.79)$ & & & & & & \\
\hline \multirow[t]{6}{*}{ Bi-normal } & $k_{1}$ & 2.57 & $12.98(0.32)$ & $1.37(0.33)$ & $20.07(3.37)$ & 13.93(7.41) & 76.70 & 46 \\
\hline & $k_{2}$ & 0.10 & & & & & & \\
\hline & $k_{3}$ & 3.22 & & & & & & \\
\hline & $k_{4}$ & 0.47 & & & & & & \\
\hline & $C$ & 1.21 & & & & & & \\
\hline & & \multicolumn{7}{|c|}{ Fishing power $\alpha$ mesh size } \\
\hline Model & Parameters & Estimates & Mode 1 & Spread 1 & Mode 2 & Spread 2 & Deviance & df \\
\hline \multirow{2}{*}{$\begin{array}{l}\text { Normal } \\
\text { location }\end{array}$} & $k$ & $4.38(0.29)$ & $17.52(1.16)$ & $10.87(1.78)$ & - & - & 99.02 & 49 \\
\hline & $\sigma$ & $10.87(1.78)$ & & & & & & \\
\hline \multirow[t]{2}{*}{ Normal scale } & $k_{1}$ & $5.02(0.36)$ & $20.11(1.45)$ & $7.53(1.31)$ & - & - & 113.97 & 49 \\
\hline & $k_{2}$ & $3.54(1.24)$ & & & & & & \\
\hline \multirow[t]{2}{*}{ Lognormal } & $\mu_{1}$ & $2.98(0.08)$ & $17.26(1.08)$ & $8.14(1.80)$ & - & - & 97.95 & 49 \\
\hline & $\sigma$ & $0.37(0.04)$ & & & & & & \\
\hline \multirow[t]{2}{*}{ Gamma } & $\mathrm{k}$ & $0.62(0.17)$ & $18.17(1.17)$ & $7.20(1.21)$ & - & - & 102.71 & 49 \\
\hline & $a$ & $8.24(1.79)$ & & & & & & \\
\hline \multirow[t]{5}{*}{ Bi-normal } & $k_{1}$ & 2.58 & $13.12(0.34)$ & $1.38(0.34)$ & $25.06(5.92)$ & $17.40(11.11)$ & 76.70 & 46 \\
\hline & $k_{2}$ & 0.13 & & & & & & \\
\hline & $k_{3}$ & 3.44 & & & & & & \\
\hline & $k_{4}$ & 0.47 & & & & & & \\
\hline & $C$ & 0.67 & & & & & & \\
\hline
\end{tabular}

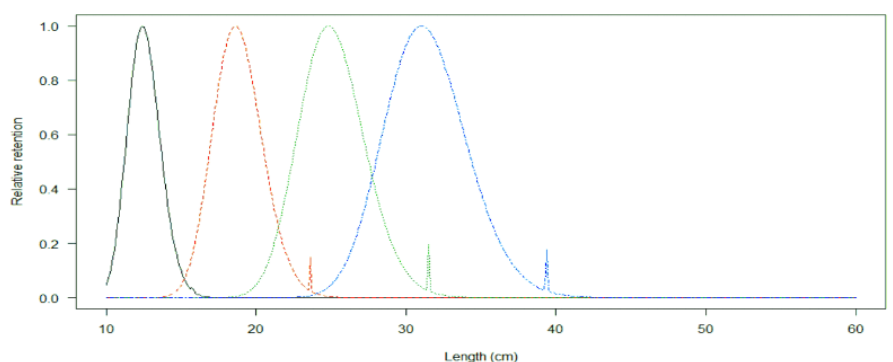

Deviance residuals

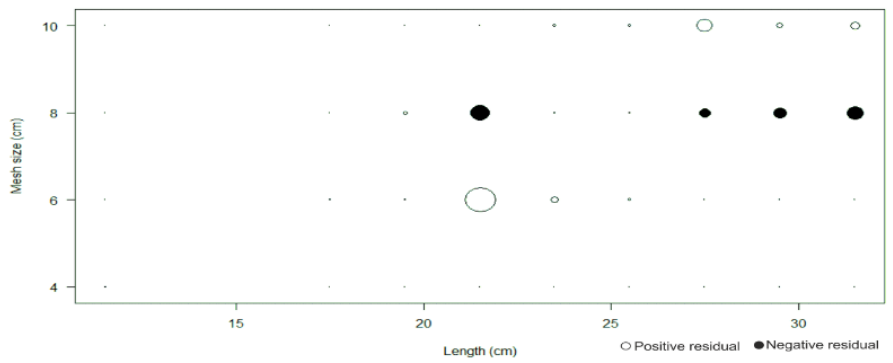

Figure 5. Selectivity curves and deviance residual plots of gillnets for the common carp 
Table 3. Selectivity model parameters of common carp and estimated selection curves for the $4 \mathrm{~cm}$ mesh size for the gillnets

\begin{tabular}{|c|c|c|c|c|c|c|c|c|}
\hline \multirow{2}{*}{ Model } & \multirow{2}{*}{ Parameters } & \multicolumn{7}{|c|}{ Equal fishing power } \\
\hline & & Estimates & Mode 1 & Spread 1 & Mode 2 & Spread 2 & Deviance & df \\
\hline \multirow{2}{*}{$\begin{array}{l}\text { Normal } \\
\text { location }\end{array}$} & $k$ & $3.12(0.05)$ & $12.48(0.22)$ & $2.48(0.29)$ & - & - & 13.78 & 25 \\
\hline & $\sigma$ & $2.48(0.29)$ & & & & & & \\
\hline \multirow[t]{2}{*}{ Normal scale } & $k_{1}$ & $3.18(0.06)$ & $12.74(0.26)$ & $1.25(0.17)$ & - & - & 10.86 & 25 \\
\hline & $k_{2}$ & $0.09(0.02)$ & & & & & & \\
\hline \multirow[t]{2}{*}{ Lognormal } & $\mu_{1}$ & $2.53(0.02)$ & $12.53(0.24)$ & $1.25(0.18)$ & - & - & 10.18 & 25 \\
\hline & $\sigma$ & $0.09(0.01)$ & & & & & & \\
\hline \multirow[t]{2}{*}{ Gamma } & $k$ & $0.03(0.00)$ & $12.60(0.24)$ & $1.25(0.17)$ & - & - & 10.35 & 25 \\
\hline & $a$ & 102.(27.81) & & & & & & \\
\hline \multirow[t]{5}{*}{ Bi-normal } & $k_{1}$ & 2.52 & $12.40(0.23)$ & $1.10(0.22)$ & $15.75(0.02)$ & $0.02(0.08)$ & 7.60 & 22 \\
\hline & $k_{2}$ & 0.08 & & & & & & \\
\hline & $k_{3}$ & 2.75 & & & & & & \\
\hline & $k_{4}$ & 0.001 & & & & & & \\
\hline & $\mathrm{C}$ & 1.76 & & & & & & \\
\hline \multirow{2}{*}{ Model } & \multirow{2}{*}{ Parameters } & \multicolumn{7}{|c|}{ Fishing power a mesh size } \\
\hline & & Estimates & Mode 1 & Spread 1 & Mode 2 & Spread 2 & Deviance & df \\
\hline \multirow{2}{*}{$\begin{array}{l}\text { Normal } \\
\text { location }\end{array}$} & $k$ & $3.15(0.05)$ & $12.61(0.23)$ & $2.52(0.30)$ & - & - & 13.00 & 25 \\
\hline & $\sigma$ & $2.52(0.30)$ & & & & & & \\
\hline \multirow[t]{2}{*}{ Normal scale } & $k_{1}$ & $3.21(0.06)$ & $12.87(0.27)$ & $1.25(0.17)$ & - & - & 10.87 & 25 \\
\hline & $k_{2}$ & $0.09(0.02)$ & & & & & & \\
\hline \multirow[t]{2}{*}{ Lognormal } & $\mu_{1}$ & $2.54(0.02)$ & $12.66(0.25)$ & $1.26(0.18)$ & - & - & 10.18 & 25 \\
\hline & $\sigma$ & $0.09(0.01)$ & & & & & & \\
\hline \multirow[t]{2}{*}{ Gamma } & $k$ & $0.03(0.008)$ & $12.73(0.26)$ & $1.26(0.18)$ & - & - & 10.35 & 25 \\
\hline & $a$ & $103.97(27.8)$ & & & & & & \\
\hline \multirow[t]{5}{*}{ Bi-normal } & $k_{1}$ & 2.53 & $12.51(0.19)$ & $1.12(0.12)$ & $15.75(0.03)$ & $0.02(0.09)$ & 8.32 & 22 \\
\hline & $k_{2}$ & 0.08 & & & & & & \\
\hline & $k_{3}$ & 2.75 & & & & & & \\
\hline & $k_{4}$ & 0.001 & & & & & & \\
\hline & $c$ & 2.11 & & & & & & \\
\hline
\end{tabular}

Modal lengths which determinate as for $4 \mathrm{~cm}$ mesh size used estimating all other mesh sizes (constant $x$ mesh size) model length with constant shown in Table 4 . For $40 \mathrm{~cm}$ MLS regulation as using constant, calculated minimum mesh size as
$12.33 \mathrm{~cm}$ for trammel and $12.90 \mathrm{~cm}$ for gillnet (Table 4). It is seeing that the model lengths are very close each other for small mesh size, while increasing mesh size enhanced the differences between model lengths (Figure 6).

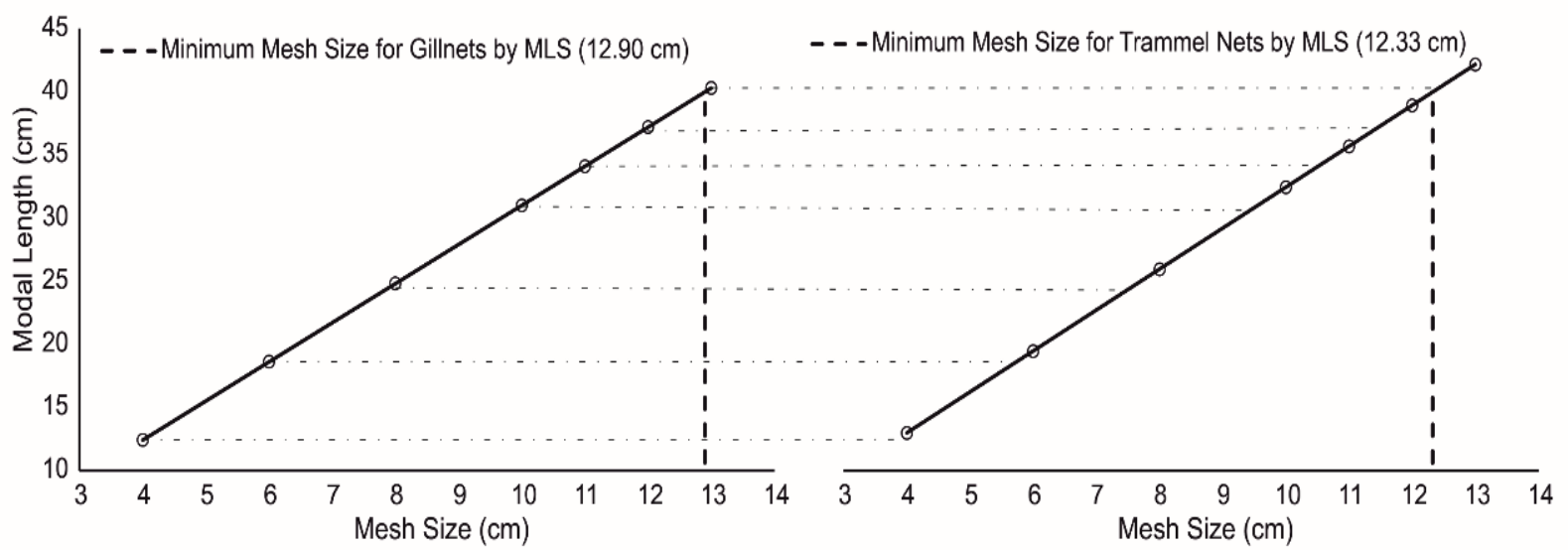

Figure 6. Model length comparison of gillnets and trammel nets 
Table 4. Model length and spread values of common carp according to the bi-normal model both trammel nets and gillnets

\begin{tabular}{|c|c|c|c|c|c|}
\hline \multirow{2}{*}{\multicolumn{2}{|c|}{$\begin{array}{l}\text { Mesh size } \\
\quad(\mathrm{cm})\end{array}$}} & \multicolumn{2}{|c|}{ Trammel Nets } & \multicolumn{2}{|c|}{ Gillnets } \\
\hline & & $\begin{array}{l}\text { Model Length } \\
(\mathrm{cm})\end{array}$ & $\begin{array}{c}\text { Spread Value } \\
(\mathrm{cm})\end{array}$ & $\begin{array}{l}\text { Model Length } \\
(\mathrm{cm})\end{array}$ & $\begin{array}{c}\text { Spread Value } \\
(\mathrm{cm})\end{array}$ \\
\hline \multirow{4}{*}{$\begin{array}{l}\mathbb{D} \\
\stackrel{\mathscr{S}}{\supset}\end{array}$} & 4 & 12.98 & 1.37 & 12.40 & 1.10 \\
\hline & 6 & 19.47 & 2.06 & 18.60 & 1.65 \\
\hline & 8 & 25.96 & 2.74 & 24.80 & 2.20 \\
\hline & 10 & 32.45 & 3.43 & 31.00 & 2.75 \\
\hline \multirow{4}{*}{$\begin{array}{l}\frac{\bar{d}}{\bar{D}} \\
\frac{\bar{D}}{\mathrm{D}} \\
\end{array}$} & 11 & 35.70 & 3.77 & 34.10 & 3.03 \\
\hline & 12 & 38.94 & 4.11 & 37.20 & 3.30 \\
\hline & 13 & 42.19 & 4.45 & 40.30 & 3.58 \\
\hline & 14 & 45.43 & 4.80 & 43.40 & 3.85 \\
\hline \multicolumn{2}{|c|}{ Constant } & $3.245^{\mathrm{a}}$ & $0.3425^{b}$ & $3.100^{c}$ & $0.275^{d}$ \\
\hline
\end{tabular}

According to the K-S test, there are significantly differences for 4, 6 and $10 \mathrm{~cm}$ trammel and gillnet specimens. Significant differences (t-test, $P<0.05$ ) were determined on average total length of catch between trammel and gillnets for $4,6,8 \mathrm{~cm}$ mesh size, but no statistical differences $(P>0.05)$ were found for $10 \mathrm{~cm}$ mesh size (Table 5). This might be due to the limited specimens in $10 \mathrm{~cm}$ mesh size experiments.

Table 5. Kolmogorov-Smirnov (K-S) and t-test result

\begin{tabular}{|c|c|c|c|c|c|c|}
\hline \multirow{2}{*}{$\begin{array}{l}\text { Trammel Nets } \\
\text { Mesh Size } \\
\text { (cm) }\end{array}$} & \multirow{2}{*}{$\begin{array}{l}\text { Gillnet } \\
\text { Mesh Size } \\
\text { (cm) }\end{array}$} & \multicolumn{3}{|c|}{ Kolmogorov-Smirnov Test } & \multicolumn{2}{|c|}{$t$-test } \\
\hline & & $D$ max & Critical Values & Decision & $\mathbf{F}$ & $p$ \\
\hline 4 & 4 & 0.5000 & 0.6319 & $\mathrm{H}_{0}$ Not Reject & 39.55 & 0.000 \\
\hline 6 & 6 & 0.5556 & 0.5606 & $\mathrm{H}_{0}$ Not Reject & 6.69 & 0.018 \\
\hline 8 & 8 & 0.7797 & 0.3192 & $\mathrm{H}_{0}$ Reject & 9.64 & 0.003 \\
\hline 10 & 10 & 0.5556 & 0.7586 & $\mathrm{H}_{0}$ Not Reject & 2.92 & 0.125 \\
\hline
\end{tabular}

\section{DISCUSSION}

Trammel nets have found more productive than gillnets. This result supported with Balık (1996) who reported multifilament trammel nets 3.08 times efficient then multifilament gillnets in common carp fishing in Beyşehir Lake. Moreover, Karakulak and Erk (2008) found a clear difference between catching efficiency trammel and gillnets. In addition, Thomas et al. (2003) presented that trammel nets caught on average two times more prawns than monofilament gill net on penaeid prawns.

There are gap between maximum lengths class of trammel and gillnets specimens. The reason might be due to the gillnetting. Fabi et al. (2002) reported that most of fishes were obtained by gilling and/or wedging. Therefore, the proportion of fish caught in this way was smallest and generally negligible in gillnets, larger in monofilament nets and largest in the standard trammel nets. In the same way, Karakulak and Erk (2008) given that model lengths of $16 \mathrm{~mm}$ trammel nets with $16 \mathrm{~mm}$ model lengths reported as $16.20,8.82,14.70,14.16$ and 13.22 for bogue (Boops boops), annular sea bream (Diplodus annularis), striped red mullet (Mullus surmuletus), axillary sea bream (Pagellus acarne) and blotched picarel (Spicara maena), respectively and gillnet as 15.28, 8.86, 13.68, 12.19 and 13.42 $\mathrm{cm} B$. boops, $D$. annularis, $M$. surmuletus, $P$. acarne and $S$. maena, respectively.

There are some studies conducted on determination of selectivity properties both gill and trammel nets. Fabi et al. (2002) used the Sechin method to estimate the gear selectivity of Lithognathus mormyrus, D. annularis and Mullus barbatus caught by gill and trammel nets. Karakulak and Erk (2008) utilized the SELECT method to compare the gillnet vs trammel nets selectivity of $B$. boops, $D$. annularis, $M$. surmuletus, $P$. acarne and S. maena. Park et al. (2011) used the SELECT method to estimate the gill and trammel selectivity of Korean flounder (Glyptocephalus stelleri). Due to the no study conducted on trammel and gillnet selectivity for $C$. carpio from same region and same fishing time, we could not directly compare with other studies. 
When comparison with previously studies conducted on gillnet for common carp (Table 6), similar optimum length were found by Balık (1999) with $13 \mathrm{~cm}$ mesh size $(39.33 \mathrm{~cm})$ and Yalçın (2006) with $10(30.4 \mathrm{~cm})$ and $12 \mathrm{~cm}(36.5 \mathrm{~cm})$ mesh sizes. However, Cilbiz et al. (2015) presented model lengths of 10,12 and $14 \mathrm{~cm}$ mesh size of trammel nets as $39.05 \mathrm{~cm}, 46.85$ $\mathrm{cm}$ and $54.66 \mathrm{~cm}$ from Lake Manyas, respectively. In addition, model lengths reported by Carol and Garcia-Berthou (2007) for $10.15 \mathrm{~cm}$ mesh size of gillnets $(38.12 \mathrm{~cm})$ very higher then ours $10 \mathrm{~cm}$ mesh size result $(31.00 \mathrm{~cm})$. It is thought that the differences might be due to the habitat variation and net material.

One of the basic principles of responsible fishery, fish has reproduced at least once before captured. The optimum selection length of the fishing gear should ideally be same as size of the fish at first maturity. In this context MLS reported as $40 \mathrm{~cm}$ in the notification below $13 \mathrm{~cm}$ mesh size should not be used for common carp fishery. Besides, in order to get definite conclusion more study need to be investigated with $11,12,13$ and $14 \mathrm{~cm}$ mesh size of both trammel and gillnets.

Table 6. Some selectivity studies conducted on common carp

\begin{tabular}{|c|c|c|c|c|c|c|}
\hline Author & Location & Method & $\mathbf{N}$ & Mesh Size $(\mathrm{mm})$ & Material & $\begin{array}{l}\text { Model Length } \\
(\mathrm{cm})\end{array}$ \\
\hline \multirow[t]{4}{*}{ (Özyurt and Avşar, 2005) } & Seyhan Dam Lake & Holt & 294 & $28^{c}$ & Monofilament & 17.55 \\
\hline & & & & $32^{c}$ & Gillnets & 20.06 \\
\hline & & & & $40^{c}$ & & 24.44 \\
\hline & & & & $45^{c}$ & & 27.50 \\
\hline \multirow[t]{4}{*}{ (Balık, 1999) } & Beyşehir Lake & Holt & 352 & $70^{a}$ & Monofilament & 18.07 \\
\hline & & & & $80^{a}$ & Gillnets & 20.66 \\
\hline & & & & $130^{\mathrm{a}}$ & & 39.33 \\
\hline & & & & $140^{\mathrm{a}}$ & & 42.35 \\
\hline \multirow[t]{4}{*}{ (Yalçın, 2006) } & Different Anatolian & Holt & 1139 & $45^{b}$ & - & 27.4 \\
\hline & Reservoirs & & & $50^{b}$ & Gillnets & 30.4 \\
\hline & & & & $55^{b}$ & & 33.4 \\
\hline & & & & $60^{b}$ & & 36.5 \\
\hline \multirow{10}{*}{$\begin{array}{l}\text { (Carol and García-Berthou, } \\
2007 \text { ) }\end{array}$} & Different Reservoirs & SELECT & 116 & $29^{a}$ & Monofilament & 10.89 \\
\hline & in Catalonia (NE & & & $38^{a}$ & Gillnets & 14.27 \\
\hline & Spain) & & & $51 a$ & & 19.15 \\
\hline & & & & $64^{a}$ & & 24.03 \\
\hline & & & & $84.5^{\mathrm{a}}$ & & 31.73 \\
\hline & & & & $101.5^{\mathrm{a}}$ & & 38.12 \\
\hline & & & & $135.5^{\mathrm{a}}$ & & 50.89 \\
\hline & & & & $177.5^{\mathrm{a}}$ & & 66.66 \\
\hline & & & & $201.5^{\mathrm{a}}$ & & 75.67 \\
\hline & & & & $253^{a}$ & & 95.01 \\
\hline \multirow[t]{5}{*}{ (Cilbiz et al., 2015) } & Manyas Lake & SELECT & 208 & $100^{a}$ & Monofilament & 39.05 \\
\hline & & & & $110^{a}$ & Trammel nets & 42.95 \\
\hline & & & & $120^{a}$ & & 46.85 \\
\hline & & & & $130^{a}$ & & 50.76 \\
\hline & & & & $140^{a}$ & & 54.66 \\
\hline \multirow[t]{16}{*}{ Present study } & Lake Marmara & SELECT & 40 & $4^{a}$ & Multifilament & 12.98 \\
\hline & & & & $6^{a}$ & Gillnets & 19.47 \\
\hline & & & & $8^{a}$ & & 25.96 \\
\hline & & & & $10^{a}$ & & 32.45 \\
\hline & & & & $11^{a}$ & & 35.70 \\
\hline & & & & $12^{a}$ & & 38.94 \\
\hline & & & & $13^{a}$ & & 42.19 \\
\hline & & & & $14^{a}$ & & 45.43 \\
\hline & & & 79 & $4^{a}$ & Multifilament & 12.40 \\
\hline & & & & $6^{a}$ & Trammel Nets & 18.60 \\
\hline & & & & $8^{a}$ & & 24.80 \\
\hline & & & & $10^{a}$ & & 31.00 \\
\hline & & & & $11^{a}$ & & 34.10 \\
\hline & & & & $12^{a}$ & & 37.20 \\
\hline & & & & $13^{a}$ & & 40.30 \\
\hline & & & & $14^{a}$ & & 43.40 \\
\hline
\end{tabular}

a mesh size (stretched); ${ }^{\text {b }}$ mesh size (bar length); ${ }^{\text { not defined }}$

\section{Acknowledgements}

We thank the Ege University Scientific Research Projects
Commission for their support with the project (Project No: 2011/SÜF/040). 


\section{REFERENCES}

Anonymous, (2008). The commercial fish catching regulations in seas and inland waters in 2008-2012 fishing period: circular No. 2008/48 (in Turkish). Republic of Turkey. Minister of Agriculture and Rural Affair, General Directorate of Conservation and Inspection, Ankara. 108. pp.

Arı, Y. \& Derinöz, B. (2011). How not to manage a wetland? The case of Lake Marmara (Manisa) with a cultural ecological perspective (in Turkish). Coğrafi Bilimler Dergisi, 9 (1): 41-60. doi: 10.1501/Cogbil_0000000117

Balık, İ. (1996). The Investigation of Selectivity and Productivity of Multifilament Trammel Net and Multifilament Gill Net and Monofilament Gill Net That Used on Fishing for Carp Fish (Cyprinus carpio L. 1758) and Pike-Perch (Stizostedion lucioperca (L. 1758)) in Lake Beysehir (in Turkish). PhD Thesis, Ege University Graduate School of Natural and Applied Science, Bornova/Izmir/Turkey.

Balık, I. (1999). Investigation of the selectivity of monofilament gill nets used in carp fishing (Cyprinus carpio L., 1758) in Lake Beyşehir. Turkish Journal of Zoology, 23(2): 185-187.

Carol, J. \& García-Berthou, E. (2007). Gillnet selectivity and its relationship with body shape for eight freshwater fish species. Journal of Applied Ichthyology, 23 (6): 654-660. doi: 10.1111/j.1439-0426.2007.00871.x

Cilbiz, M., Küçükkara, R., Ceylan, M., Savaşer, S. \& Meke, T. (2015). Tramme Net Selectivity of Common Carp (Cyprinus carpio L., 1758) in Manyas Lake, Turkey. Journal of Limnology and Freshwater Fisheries Research, 1 (1): 1-7. doi: 10.17216/LimnoFish-5000083989

Fabi, G., Sbrana, M., Biagi, F., Grati, F., Leonori, I. \& Sartor, P. (2002). Tramme net and gill net selectivity for Lithognathus mormyrus (L., 1758), Diplodus annularis (L., 1758) and Mullus barbatus (L., 1758) in the Adriatic and Ligurian Seas. Fisheries Research, 54 (3): 375-388. doi: 10.1016/S0165-7836(01)00270-3

Emiroğlu, Ö. (2011). Alien fish species in upper Sakarya River and their distribution. African Journal of Biotechnology, 10 (73): 16674-16681. doi:10.5897/AJB10.2502

Holt, S.J. (1963). A method for determining gear selectivity and its application. ICNAF Special Publication, 5: 106-115.

Illhan, A. \& Sarı, H.M. (2013): Fish fauna and fisheries activities in Lake Marmara (in Turkish). Ege Journal of Fisheries and Aquatic Sciences, 30 (4): 187-191. doi: 10.12714/egejfas.2013.30.04.08

Karakulak, F. S. \& Erk, H. (2008). Gill net and trammel net selectivity in the northern Aegean Sea, Turkey. Scientia Marina, 72 (3): 527-540.

Millar, R.B. (1992). Estimating the Size-Selectivity of Fishing Gear by Conditioning on the Total Catch. Journal of the American Statistical Association, 87(420): 962-968. doi: 10.2307/2290632
Millar, R.B. \& Fryer, R.J. (1999). Estimating the size-selection curves of towed gears, traps, nets and hooks. Reviews in Fish Biology and Fisheries, 9 (1): 89-116.

Millar, R.B. \& Holst, R. (1997). Estimation of gillnet and hook selectivity using log-linear models. ICES Journal of Marine Science, 54 (3): 471-477.

Millar, R.B. (2009). R Code for fitting SELECT models to gillnet data. In: Department of Statistics, University of Auckland, New Zealand. Retrieved from https://www.stat.auckland.ac.nz/ millar/selectware/R/gillnets/ (Accessed: 25.02.2016).

Millar, R.B. (2010). R Code for fitting SELECT models to gillnet data. In: Department of Statistics, University of Auckland, New Zealand. Retrieved from https://www.stat.auckland.ac.nz/ millar/selectware/RNext/ (Accessed:25.02.2016).

Özyurt, C. E. \& Avşar, D. (2005). Investigation of the selectivity parameters for carp (Cyprinus carpio Linnaeus, 1758) in Seyhan Dam Lake. Turkish Journal of Veterinary and Animal Sciences, 29 (2): 219-223.

Park, H. H., Millar, R. B., Bae, B.-S., An, H. C., Chun, Y. Y., Yang, J. H. \& Yoon, S. C. (2011). Size selectivity of Korean flounder (Glyptocephalus stelleri) by gillnets and trammel nets using an extension of SELECT for experiments with differing mesh sizes. Fisheries Research, 107(1-3): 196200. doi: 10.1016/j.fishres.2010.10.020

Siegel, J. \& Castellan, N. S. (1989). Non parametric statistics for the behavioural sciences. Statistics Series, $2^{\text {nd }}$ Edition: Mc Graw Hill, New York.

Thomas, S.N., Edwin, L. \& George, V.C. (2003). Catching efficiency of gill nets and trammel nets for penaeid prawns. Fisheries Research, 60(1): 141150. doi: 10.1016/S0165-7836(02)00057-7

TUIK (2015). Turkey Statistical Institute. Fishery Statistics. Retrieved from http://www.turkstat.gov.tr/PreTablo.do?alt_id=1005 (Accessed: 23.02. 2016)

Yalçın, N. (2006). Comparison of the Selectivity Parameters for Common Carp (Cyprinus carpio L, 1758) and Mirror Carp (Cyprinus carpio L., 1758 var. specularis) in Dam Lakes (in Turkish). Ist Fish Introduction and Reservoir Management Symposium, 07-09. February 2006 Antalya.p 281-288 (Full text available in Akuademi.net).

Yüksel, F., Gündüz, F. \& Demirol, F. (2014). Gillnet selectivity for Luciobarbus esocinus (Heckel, 1843) in Keban Dam Lake, Elaziğ, Turkey. Indian Journal of Fisheries, 61 (2): 108-111. 